ББК 63.3(0)5; УДК 94(498); DOI 10.21638/11701/spbu19.2017.211

R. Mârza

\title{
TEACHING SLAVIC HISTORY IN ROMANIA IN 2017
}

My contribution relies on my experience of more than ten years in teaching a university course of Slavic history in Romania. The course and seminar are entitled «The Slavs and Slavonism in the Medieval and Early Modern History of the Romanians» ["Slavii şi slavonismul în istoria medievală şi premodernă a românilor»]. It is a special course taught to third year students, BA level, at the History of Philosophy Faculty of the Babeş-Bolyai University in Cluj. For several years now, this teaching experience has led me to several questions regarding the opportunity of offering such a course from a didactic perspective, how it connects to the times we live in, the manner in which such a course should be prepared according to the education, expectations, and needs of our students. I continue to find answers to these questions throughout the years and on this occasion I shall attempt to formulate them.

I will begin by presenting briefly the history of Slavic Studies in Romania, as an academic discipline. In Romania, scientific interest into Slavic Studies (Slavistics) dates back to the second half of the $19^{\text {th }}$ century. Such interests appeared as a result of Romanian historiography, culture, and society becoming modern and mature. For almost a century (from the end of the $18^{\text {th }}$ century until the mid-19 $9^{\text {th }}$ century), the historiography of the Enlightenment and of Romanticism have revealed the Latin historical and linguistic factors as fundamental, even exclusive ones in the formation of the Romanian people and language. Around 1780-1820, Petru Maior, Gheorghe Şincai, Samuil Micu, and Ioan Budai-Deleanu, Romanian scholars from Transylvania, Greek-Catholics formed at the schools and universities of Buda, Vienna, Rome, and Trnava, have transformed stressing the Latin character of the Romanian nation and language into an actual platform, taking this discourse from the cultural and academic environments to the political ones and spreading it among the public. By stressing and overvaluing the Latin elements, understandable in context, they ended up denying the nonLatin elements of the Romanian language (Slavic, Greek, Turkish etc.), denying the role of the Cyrillic alphabet that they deemed not representative for the spirit of the Romanian language, and disregarding certain moments of Romanian medieval history and culture, especially those associated with the Slavs, the Bulgarian influence etc. ${ }^{1}$

${ }^{1}$ Mârza R. History of Romanian Slavic Studies. Cluj-Napoca, 2008. P. 93-119.

(C) R. Mârza, 2017 
Another generation of Transylvanian scholars, with an even more radical discourse, followed those mentioned above, known under the generic term of «The Transylvanian School» (Şcoala Ardeleană). The new generation is known as «The Latinist School» (Şcoala Latinistă), with representatives such as Florian Aaron, August Treboniu Laurian, Alexandru Papiu-Ilarian, Timotei Cipariu, Aron Pumnul, and Ioan Maiorescu. The major difference resides in the fact that this new generation has also promoted its discourse outside Transylvania. Many of its representatives ended up, especially after the 1848-1849 revolutions, in Bukovina, Walachia, and Moldavia. In the two Romanian Principalities, the so called «Transylvanian doctors» (doctorii ardeleni) (ironically called thus in Walachia and Moldova) held important positions in the administration, government, justice, media, and primary and secondary education; some of them were among the founders of the Iaşi and Bucharest universities in 1860 and 1864, and of the Romanian Academic Society (the future Romanian Academy) in 1866. Through them, Latinist discourse permeated schoolbooks, political discourse, and public awareness ${ }^{2}$.

It was only several decades later that certain personalities and cultural circles appeared and started to question the Latinist discourse. They began discussing on a more objective and a more balanced note the issue of Romanian origins and language. The representative figures of this historiographic trend were encyclopedic scholar Bogdan Petriceicu Hasdeu, born in Bessarabia and a good speaker of Polish and Russian³, Vasile Alecsandri, Alecu Russo, Mihail Kogălniceanu, and the very important and influential group around «Junimea» in Iaşi (Titu Maiorescu, Iacob Negruzzi, and Vasile Pogor), together with its excellent publication Convorbiri Literare [Literary Conversations]. During the 1860s-1900s, «Junimea» was the equivalent of critical spirit and it had a major contribution to modernizing Romanian historical writing ${ }^{4}$. One must also mention here Alexandru Odobescu, Grigore Tocilescu, and bishop Melchisedec Ştefănescu 5 . This context saw the first historical researches and publications that revealed the historical Romanian-Slavic connections, the importance of Slavonic culture, of the Cyrillic alphabet and of Slavonic mass for Romanian medieval history and culture. One notes the first researches dealing with the issue of the Slavic linguistic influences upon Romanian language. The first collective volumes and corpuses of Slavonic documents were published during this period and the numerous medieval written sources in Slavonic and with Cyrillic alphabet were signaled, published, and valorized.

The first «Slavonic philology» university departments were thus created in this novel context at the universities of Bucharest and Iaşi $(1891,1905)$, founded by the great slavists Ioan Bogdan and Ilie Bărbulescu ${ }^{6}$. Their introductory lectures are true didactic and research

2 Mârza R. History of Romanian Slavic Studies. P. 125-144.

3 Mârza R. 1) Identităţile slave ale lui Bogdan Petriceicu Hasdeu // Identitate şi alteritate. 4. Studii de istorie politică şi culturală / Ed. by C. Bărbulescu, L. Dumănescu, S. Mitu, V. Popovici. Cluj-Napoca, 2007. P. 259-273; 2) A Bibliography of Bogdan Petriceicu Hasdeu's Concerns in the Field of Slavonic Studies // Transylvanian Review. 2003. Vol. XII. No. 2. P. 118-130; Pecican O. B. P. Hasdeu istoric. Cluj-Napoca, 2004.

4 Ornea Z. Junimea şi junimismul. Bucureşti, 1975.

5 Mârza R. History of Romanian Slavic Studies. P. 171-173, 241-244, 344-357.

6 Mârza R. 1) History of Romanian Slavic Studies. P. 269-278; 2) Ilie Bărbulescu și înființarea catedrei de limbi slavice la Universitatea din Iași. Contribuții documentare // Clio în oglindiri de sine. Academicianului Alexandru Zub. Omagiu / Ed. by G. Cliveti. Iaşi, 2014. P. 631-660. Also see: Lința E. 
programs that gave momentum to the development of Slavic Studies ${ }^{7}$. Ioan Bogdan was a truly representative personality in the field, the actual founder of Romanian Slavic Studies, who asserted himself through the courses, publications and not least through his students who continued his researches ${ }^{8}$. That was the moment when Slavic Studies became established as an interdisciplinary, historical, and philological discipline in the environment of academic research in Romania. The organization of the two departments of the universities of Bucharest and Iaşi has led to the development of the field of studies through the students who followed it and took it forward, through the taught courses and seminars, and through the publications of both professors and students that have led to the formation of a body of specialized literature . $^{9}$ During the $20^{\text {th }}$ century and the beginning of the $21^{\text {th }}$ century, Slavic Studies in Romanian universities inherited and developed the discipline and the interests and research directions of those who founded it around the year 1900.

After 1918, Slavic Studies in Romanian universities went through great developments and became more diverse. New departments were created, besides those in Bucharest and Iaşi: at the universities in Chernivtsi (Rom. Cernău $\square$ i, Germ. Czernowitz) (two Slavic Studies departments existed there ever since the time of the old «Franz Joseph» University) ${ }^{10}$ and in Cluj (the South-Eastern European History department). In various institutional forms, the Slavic Studies departments provided courses and seminars of Slavic philology, literature, history, culture and not least of Slavic languages (Russian, Polish). Among the professors who honored this discipline one can mention philologists and historians such as Petre Cancel, Ecaterina Piscupescu, Petre P. Panaitescu (Bucharest), Ilie Bărbulescu, Margareta Ştefănescu (Iaşi), Iosif Popovici, Theodor Capidan, Emil Petrovici, Silviu Dragomir, Mihail P. Dan (Cluj), and Ioan Nistor (Chernivtsi).

Slavic Studies grew in Romania after 1944, following the country's occupation by the Red Army and the onset of the Communist regime ${ }^{11}$. One of the cultural leitmotifs of the new regime was the ancient character and consistency of the historical and cultural RomanianSlavic connections, especially of the Romanian-Russian link. This cultural line was, among other things, visible in the unprecedented development of Slavic and Russian Studies in the universities of Romania. For example, departments of Slavic Studies, Russian language and Russian literature functioned after 1948 at the University of Bucharest, though they went through several transformations over the decades. This was the age of great professors, such as Gheorghe Mihăilă ${ }^{12}$, Emil Petrovici, I. C. Chițimia, Pandele Olteanu, and Lucia Djamo-

(ed.). Din istoricul slavisticii româneşti. București, 1982; Mihăilă G. O sută de ani de studii slavoromâne la Universitatea din Bucureşti // Romanoslavica. 1992. Vol. XXIX. P. 15-56.

7 Mârza R. Recitindu-i pe clasici. Lecțiile inaugurale ale lui Ioan Bogdan (1891) şi Ilie Bărbulescu (1905) // Romanoslavica. 2009. Vol. XLV. P. 153-166 (URL: http://www.romanoslavica.ro).

8 Mârza R. Ioan Bogdan: His Education and Career in the Field of Slavonic Studies // Transylvanian Review. 2006. T. XV. No. 1. P. 3-26; Mihăilă G. (ed.). Bogdan I. Scrieri alese. Bucureşti, 1968.

9 Mârza R. History of Romanian Slavic Studies. P. 271-272.

10 Mârza R. History of Romanian Slavic Studies. P. 278-281.

11 Mihăilă G. Slavistica românească după 1944 şi sarcinile ei actuale (Lucrările de lingvistică) // Romanoslavica. 1960. T. IV. P. 5-34.

12 Mihăilă G. 1) Studii de lexicologie şi istorie a lingvisticii româneşti. Bucureşti, 1973; 2) 
Diaconiță, who have not only developed Slavic Studies in general, including Slavonic language, literature, and culture ${ }^{13}$, but also the teaching of modern Slavic languages and literatures: Polish, Russian, Czech and Slovak, Bulgarian and Serbo-Croatian etc. ${ }^{14}$ During the 1980s, the teaching of Slavic Studies went through a great crisis period in Romanian universities due to the lack of political support, the lack of interest in the Slavic area (especially the Soviet one) among the students, though one could note this lack of interest among the entire Romanian society as well. The situation was partially remedied after 1989: the teaching staff was refreshed there were new perspectives, more foreign lectors came, and Romanian society experienced a great opening. Anyway, the number of students currently interested in the field is small. A department of Russian Philology ${ }^{15}$ and a department of Slavic Philology currently function part of the Foreign Languages Faculty in Bucharest ${ }^{16}$.

The same trends can be noted among the other Romanian universities where Slavic Studies (languages) were taught. In Cluj, the central personality of Slavic Studies was member of the academy Emil Petrovici, active since the 1930s, rector of the university (1945-1951) during the new regime (the current Babeş-Bolyai University). In 1948, Silviu Dragomir, a great historian and slavist was abusively retired. In this context one should also mention historian Mihail P. Dan. Today a Department of Slavic Languages and Literatures exists part of the Faculty of Letters of the Babeş-Bolyai University in Cluj. This department teaches courses and seminars in Slavic Studies in general, but the focus is on Russian language and literature. There is also a section of Ukrainian language and literature ${ }^{17}$. The university also hosts a Centre of Polish Language and Culture and a Russian Cultural Centre.

In Cluj, like in other universities from Romania, Slavic Studies have been appropriated through tradition (at least until the 1960s-1970s) not only by faculties with a philological profile, but also by faculties of history. For example, representative personalities of Romanian historical writing after 1918 were directly connected to the field of Slavic Studies, such as Silviu Dragomir and Mihail P. Dan from the university in Cluj. Silviu Dragomir completed his university studies in Chernivtsi, performed research in archives and libraries in Belgrade, Sremski Karlovci, and Moscow (1910-1911), and taught courses of Romanian Church history and courses regarding the Romanic population in the Balkans, in direct connection to the Slavic Studies at the Theological Academy in Sibiu and then at the University of Upper Dacia in Cluj (currently the Babeş-Bolyai University) ${ }^{18}$. Historian Mihail P. Dan's career peaked

Cultură şi literatură română veche în context european. Studii şi texte. Bucureşti, 1979; 3) Studii de lingvistică şi filologie. Timişoara, 1981; 4) Între Orient şi Occident. Studii de cultură şi literatură română în secolele al XV-lea - al XVIII-lea. Bucureşti, 1999; 5) Langue et culture roumaine dans l'éspace sud-est-européen. Bucureşti, 2001.

${ }^{13}$ See: Olteanu P. (ed.). Slava veche şi slavona românească. Bucureşti, 1975.

${ }^{14}$ Geambaşu C. (ed.). Catedra de limbi şi literaturi slave. Scurt istoric. Bucureşti, 2008. P. 7-11.

${ }^{15}$ URL: http://www.unibuc.ro/depts/limbi/literatura_rusa/index.php (accessed - June, 2017).

${ }^{16}$ URL: http://www.unibuc.ro/facultati/limbi/Catedre.php (accessed - June, 2017).

${ }^{17}$ URL: http://lett.ubbcluj.ro/departamente/departamentul-de-limbi-si-literaturi-slave (accessed June, 2017).

${ }^{18}$ Mârza R. 1) Slavistica şi formaţia istorică a lui Silviu Dragomir // Silviu Dragomir. 120 de ani de la naştere / Ed. by I.-A. Pop, S. Şipoş. Oradea, 2011. P. 197-208; 2) History of Romanian Slavic Studies. P. 409-413; Ghitta O. Silviu Dragomir, historien des relations ecclesiastiques roumano-russes // Transylvanian Review. 1993. T. II. No. 2. P. 53-59. 
during the 1950s-1970s when he taught several courses dedicated to the Slavic area, such as the one on the history of the peoples inside the URSS. He was very knowledgeable on the Czech-Slovak and Soviet areas ${ }^{19}$.

Unfortunately, the organic connection between philologists and historians, vital to the researches in the field of Slavic Studies, was broken starting with the 1960s-1970s and today there is no institutional tie to connect those interested in Slavic Studies. Such specialists are left with joining the same symposiums or conferences, publishing studies, articles and book reviews in the prestigious periodical Romanoslavica from Bucharest, symbol of Romanian Slavic Studies, published uninterrupted since $1958^{20}$, or with other collaborations under the patronage of the Slavic Association of Romania ${ }^{21}$.

I thus believe that presenting and discussing a course dedicated to the history of the Slavs, currently available at the Babeş-Bolyai University in Cluj, is both interesting and relevant.

Returning to the questions mentioned in the beginning of the present paper, one should dwell on the current academic, cultural, and political context. First of all, one should mention the fact that this context is far from the «favorable» era of the 1950s, when such courses were often included in the teaching programs of many faculties and universities in Romania. Nowadays, Romania has abandoned its «traditional connections» to Russia, has left the «Warsaw Pact» (1991), and is a member of NATO and the EU (still, together with many Slavic states!). What is more, we live in a globalized society that no longer stresses ethnic associations and solidarities, where the general interests of Romanian society, including those of the students to whom such a course is addressed, have changed radically.

The education of the future students does not focus on what is traditionally called «general knowledge». The education in history, geography, and world literature that Romanian primary and secondary school pupils receive is modest, thus there is little chance they possess minimal data on the Slavic world. Thus, the first activity part of the course «The Slavs and Slavonism in the Medieval and Early Modern History of the Romanians» consists of administering students a questionnaire with general questions on the Slavic peoples, their geographic location, their historical connections to the Romanians, on historical personalities and events in the Slavic world, and specialized terms ${ }^{22}$.

Three-year Bologna-style university studies provide history students with a strictly general education, as specialization only truly starts with the master and doctoral studies. It is the reason why faculties can only offer few very specialized courses and students have low expectations.

Thus the question: is there any point in teaching such a course?

The answer is affirmative. Such a course is necessary in the history students' curriculum for several reasons. These reasons remind of the considerations expressed more than a century ago by the founders of the university departments in Bucharest and Iaşi, Ioan Bogdan and Ilie Bărbulescu, who stressed the usefulness of Slavic Studies in the research of both past and

19 Mârza R. Istoricul Mihail P. Dan (1911-1976) // Caietele «David Prodan». 1994. T. I. No. 1. P. $50-57$.

20 URL: http://www.romanoslavica.ro/ (accessed - June 2017).

21 URL: http://www.romanoslavica.ro/asociatie.htm (accessed - June 2017).

22 Link to the syllabus of the course: http://hiphi.ubbcluj.ro/Public/File/syllabus/istorie/Slavii si slavonismul 2014.pdf. 
present $^{23}$. The reasons have largely remained unchanged. First of all, the historic and linguistic connections to the Slavic world are fundamental to understanding the key historical processes of the Romanian Early Middle Ages (such as ethnogenesis and the formation of the Romanian language), the social, cultural, institutional, and religious history of the Romanians during the Middle Ages, their connections to the South Slavic area (Bulgaria, Serbia), and to the Polish, Russian-Ukrainian, and Western Slavic areas. The history of medieval Romanian literature or Church cannot be understood without knowledge of Slavonic culture, language, and literature. One cannot ignore either the historical Romanian-Polish or Romanian-Russian relations during the Modern Era, Romania's inter-war connections with Yugoslavia, Czechoslovakia, Poland and, why not, the connections of Romania with the Slavic countries after 1944.

There are then the challenges of the present, that make Slavic Studies interesting and useful: the historical developments in the Balkans over the last 25 years (the crises of the Yugoslav area), the international presence of Russia in the South-Eastern and Eastern European area and globally, the challenges that Ukraine faces - Romania's Northern neighbor — and even the Republic of Moldavia and its political tendencies. One cannot ignore either the multiple forms of cooperation (economic, cultural) inside the European Union between Romania and Slavic countries. Last but not least, one must mention the fact that numerous Slavic minorities currently live in Romania (Bulgarian, Czech, Croatian, Polish, Lipovan Russian, Serbian, Slovak, Ukrainian $)^{24}$, who have well established places in present-day Romanian society and the historical, linguistic, and cultural connections of which to the Romanians are accepted, affirmed, and intensely studied.

For all these reasons I believe that a university course dedicated to the history of the Slavs is always welcome in the teaching programs of the history faculties in present-day Romania.

I shall subsequently present the topics of the lectures. From the beginning, one must state that there is no clear distinction between lectures (the course) and the seminar activities, but that they are intertwined. Course activities often look like a seminar. Another important observation envisages the way lectures are structured. I tried to have a balance between general lectures, focusing on the history of the Slavs, and particular lectures dealing with the historical Romanian-Slavic relations, so that the enlisted students receive both a general historical background and elements directly connected to the Romanian area.

The first lecture is the Introduction. It clarifies the specialized terminology (Slavistics, Slavic Studies, Slavonism, Common Slavonic, Church Slavonic, modern Slavic languages), the aims, topics, and bibliography of the course, the way in which the activities are set to take place and how students will be evaluated (topic I). Then follows a lecture on the history and historiography of Slavic Studies: Slavistics in Europe and Romania (topic II), discussing the beginning of academic interest into the past, languages, and culture of the Slavs and non-Slavs among the Romanians. It also provides students with case studies regarding the beginnings of Slavistics in Romania, Russia, and the Habsburg Empire. For this topic, several students have to prepare papers on the introductory lectures of Ioan Bogdan and Ilie Bărbulescu delivered at

23 Mârza R. Recitindu-i pe clasici.

24 Istoria minorităților naționale din România / Ed. by D. Dumitrescu, C. Capita, M. Manea. Bucureşti, 2008. 
the universities of Bucharest and Iaşi ${ }^{25}$, in a comparative analysis with the introductory lecture of British historian, historian of literature and slavist William Richard Morfill (1834-1909), delivered at the University of Oxford $(1890)^{26}$. Starting from this discussion, the students are encouraged to meditate and discuss the significance of Slavic Studies in the present and to enquire as to their opportunity. Eventually, the students must write, for the subsequent meeting, an essay entitled «What are (should be) the priorities of Romanian Slavistics today?»

Then there are the general lectures, dedicated to the history of the Slavs. The three lectures bear the common title The Entry of the Slavs into European History, that is a paraphrase of A. P. Vlasto's famous 1970 work $^{27}$. One of the lectures discusses the Migration and Settlement of the Slavs in the Central, Eastern, and South-Eastern European areas. History of the Slavic Peoples during the Middle Ages and the Early Modern Era (topic III). This includes addressing issues such as the theories regarding the origin of the Slavs: the classical theory of the migration from the original country and their settling in the territories of Central and Eastern Europe, but also the «revisionist» theories, such as that of Florin Curta ${ }^{28}$. The lecture dwells on the cultural analysis of the arguments supporting each theory, on issues of language, historical geography, culture, acculturation, and two-way influences. One fundamental aspect is to place the early history of the Slavs against the geographic setting of medieval Europe (Central Europe, the Lower Danube, the Balkan Peninsula), of the Byzantine Empire and of the Byzantine Commonwealth ${ }^{29}$. This lecture requires students to write an essay on «The Slavic Expansion into the Balkans $\left(6^{\text {th }}-8^{\text {th }}\right.$ centuries $)$ », i. e. the arrival of the Slavs around Thessaloniki starting from one of the era's significant written sources - Miracula Sancti Demetrii (dated to the $7^{\text {th }}$ century) ${ }^{30}$. The essay is a pretext to evaluate the political, demographic, and cultural impact of the Slavs on the Byzantine provinces from the Balkans, but it also reveals a spectacular medieval historical source. One of the course's assumed goals is precisely the intimate understanding of medieval sources.

The subsequent lecture continues with the period of adopting Christianity and the organization of the first medieval states, presenting the history of the Slavs until the Early Modern Period (topic IV). Considering the structure of the course, one finds it impossible to go into details, so that the presentation is general in nature, though it dwells more on Bulgaria, Serbia, and Poland with which the Romanian area had close ties throughout the centuries. The subsequent lecture is a seminar activity, dedicated to several interesting case studies from the history of the Slavic peoples adopting Christianity (topic V). Students must prepare essays on

25 Bogdan I. Însemnătatea studiilor slave pentru Români. Bucureşti, 1894; Bărbulescu I. Problemele capitale ale Slavisticei la Români. Iaşi, 1906.

26 Morfill W. An Essay on the Importance of the Study of the Slavonic Languages. Oxford, 1890. 27 Vlasto A. The Entry of the Slavs into Christendom. Cambridge, 1970.

28 Curta F. The Making of the Slavs: History and Archaeology of the Lower Danube Region, c. 500-700. Cambridge, 2001; and its Romanian edition: Curta F. Apariţia slavilor. Istorie şi arheologie la Dunărea de Jos în veacurile VI-VII. Târgovişte, 2006.

29 Obolensky D. The Byzantine Commonwealth. New York, 1971; and its Romanian edition: Obolensky D. Un commonwealth medieval: Bizanțul. Europa de răsărit 500-1453. Bucureşti, 2002. 30 Lemerle P. Les plus anciens recueils des miracles de Saint Démétrius et la pénétration des Slaves dans les Balkans. Vol. I. Paris, 1979. Also see: Obolensky D. The Cult of St. Demetrius of Thessaloniki in the History of Byzantine-Slav Relations // Balkan Studies. 1974. Vol. 15. P. 3-22. 
«The Byzantine Mission into Great Moravia», «Medieval Bosnia between Christianity and Islam», and «Russia Adopting Christianity under Prince Vladimir».

The following series of lectures is dedicated to the historical Romanian-Slavic connections. The shared title is "The Slavs in the Romanian Area» and the series provides three perspectives. The first is the archaeological perspective (topic VI). The presentation follows the main directions of archaeological investigations of the Slavic presence on the Romanian territory from the Migrations Period until the $10^{\text {th }}-12^{\text {th }}$ centuries, in settlements and cemeteries, especially in settlements from the Lower Danube, in Byzantine context, and in other settlements in which Slavic material coexists with autochthonous (post-Roman) material. At this point, the course discusses the challenges that archaeologists face in dealing both with written sources and political power. Besides, part of the lecture is dedicated to the ideological charge of Slavic archaeology in Romania throughout the Communist Regime ${ }^{31}$.

The second perspective is the linguistic one (topic VII), starting from the premise of the significance of linguistics in the historical research of the periods with few historical and literary sources (Late Antiquity, Migrations Period, the spread of Christianity, the early period of the medieval states). The course discusses the consequences for the Romanian language under formation of the meeting between the Romanic population North and South of the Lower Danube and the Slavs, the levels of influence between the Slavic languages and Romanian (the idioms of the Slavic peoples that settled in the Romanian territory during the $6^{\text {th }}-8^{\text {th }}$ centuries, the influence period of Slavonic, the two-way character of these influences). The lecture then signals the categories of Slavic terms that entered the Romanian language, the geographic origin of these categories of words (from Slavonic ${ }^{32}$, Middle Bulgarian, Serbian, Polish, Ukrainian, Russian etc.), but also the Romanian terms adopted in some of the Slavic languages (see the Romanian pastoral vocabulary adopted into Polish, Czech and especially Slovak $)^{33}$. A significant part of the lecture is dedicated to an introduction in etymology ${ }^{34}$, with a discussion of toponymy and hydronymy ${ }^{35}$, topics to which the students' attention is especially drawn. In the end of the lecture, they each present a toponym or hydronym that is the result of Slavic-Romanian linguist cohabitation.

The third perspective presented is the cultural one (topic VIII), discussing in general the consequences of the influence of the Slavic factor, of Slavonic language, and of Slavic liturgy on medieval Romanian culture and Romanian society in general. At this point the course also

31 See: Curta F. The changing image of the Early Slavs in the Rumanian historiography and archeological literature // Südost-Forschungen. 1994. T. 53. P. 225-310; Stanciu I. Slavii timpurii în cercetarea arheologică românească // Ephemeris Napocensis. 2001. T. XI. P. 105-132.

32 Olteanu P. (ed.). Slava veche şi slavona românească. Bucureşti, 1975; Mitu M. Slavona românească. Bucureşti, 2002.

33 Niță-Armaş S. În jurul problemei cuvintelor de origine românească în limba slovacă // Studii şi cercetări lingvistice. 1966. T. XVII. No. 5. P. 579-591; Niţă-Armaş S., Pavliuc N., Gămulescu D. L'influence roumaine sur de lexique des langues slaves // Romanoslavica. 1968. T. XVI. P. 69-70, 101 (see the list of the Romanian words at p. 72-100). Also see: Macůrek J. Valaši v západních Karpatech v 15.-18. století. K dějinám osídlení hospodářsko-společenského vývoje jižního Těšínska, jihozápadního Polska, severozápadního Slovenska a východní Moravy. Ostrava, 1959. 34 Sala M. Introducere în etimologia limbii române. Bucureşti, 2005.

35 See: Petrovici E. Studii de dialectologie şi toponimie. Bucureşti, 1970. 
discusses the (approximate) chronology of these aspects (Church, language, Cyrillic writing, influence of Slavonic literature), stressing the Byzantine-Slavic (Slavic-Byzantine) character of medieval Romanian culture. The concept of «cultural Slavonism» introduced by historian Petre P. Panaitescu is also discussed ${ }^{36}$.

The lecture detailed above is completed by a seminar-type meeting entitled RomanianSlavic cultural connections. Slavonism as part of Romanian medieval and Early Modern culture (topic $I X$ ), during which students present several essays on interesting topics. The first essay discusses «The Slavic Influence in Transylvania», starting from an inciting and controversial article published by Pandele Olteanu ${ }^{37}$. The second is called «Roman and Vlahata vs. Vita Constantini et Methodii» and attempts to establish connections between a theory regarding the origin of the Romanians (in the so-called Gesta of Roman and Vlahata from the Moldavian-Russian Chronicle written in the beginning of the $16^{\text {th }}$ century) and the Lives of Constantine and Methodius. This essay aims at drawing attention to the circulation of texts and ideas in the area of Eastern Europe and on the official character of some medieval sources $^{38}$. The third essay is also connected to the previous lecture. It discusses «The Crisis of cultural Slavonism» during the $17^{\text {th }}$ and $18^{\text {th }}$ centuries. Starting from contemporary sources (The Cazania of metropolitan Varlaam, Foreword to Antim Ivireanu's Slavonian Grammar, Udri $\square$ te Năsturel's Foreword to the Slavonic translation of De imitatione Christi of Thomas a Kempis), the essay must discuss the process of degradation of Slavonic culture, of the use of Slavonic language, and the introduction of Romanian language in culture, literature, Church etc.

The course's subsequent topics deal with the historical connections of the Romanians with the neighboring Slavic peoples and they are also structured as lectures and essays. The first topic is dedicated to the connections with the South Slavic area (topic X). Several essays are presented after the introduction that sets the research directions (political, institutional, and social history) of the connections between the Romanian territories on the one hand and Bulgaria and Serbia on the other ${ }^{39}$, including after the Ottoman conquest. The first essay is on the theory of «Bulgaria from North of the Danube», a discussion on an older study published by Petre P. Panaitescu under pseudonym in $1950^{40}$. The topic of the essay is relevant for the

36 Panaitescu P. 1) Contribuții la istoria culturii româneşti. Bucureşti, 1971; 2) Interpretări româneşti. Studii de istorie economică şi socială. Bucureşti, 1994.

37 Olteanu P. Aux origines de la culture slave dans la Transylvanie de Nord et le Maramureş // Romanoslavica. 1958. T. I. P. 169-197.

38 Pecican O. Troia, Veneția, Roma. Studii de istoria civilizației europene. Cluj-Napoca, 1998. P. 103-112; Alzati C. În inima Europei. Studii de istorie religioasă a spațiului românesc. ClujNapoca, 1998. P. 92-100.

39 Dvornik F. Slavii în istoria şi civilizaţia europeană. Bucureşti, 2001. P. 80-106; Rezachevici C. Istoria popoarelor vecine şi neamul românesc în evul mediu. Bucureşti, 1998. P. 298-380. Also see: Relații româno-bulgare de-a lungul veacurilor (sec. XII-XIX). Vol. I. Bucureşti, 1971.

40 Grecu Al. [Panaitescu Petre P.]. Bulgaria în nordul Dunării în veacurile al IX-X-lea // Studii şi Cercetări de Istorie Medie. 1950. T. I. No. 1. P. 223-236. — Due to his involvement with the Iron Guard, during the first years of the Communist Regime the historian was prohibited from publishing under his own name. See: Mârza R. Recitindu-l pe Panaitescu: Bulgaria în nordul Dunării // Studii de istoriografie românească / Ed. by G. Moisa. Cluj, 2008. P. 159-178. 
discussion started by the historian starting from the Byzantine sources that spoke of a Bulgaria North of the Danube during the first Bulgarian Tsardom; the theory has been controversial in Romanian historiography during the 1930s-1940s, when recognizing Bulgarian rule over the territory North of the Danube had been a problem. The ideological charge of the research and even of the publication of Panaitescu's study in an aggressive political context (the first years of the Communist Regime) is also interesting. Another suggested essay is dedicated to the personality of scholar and diplomat Grigore $\square$ amblac (Grigorij Camblak) $\left(14^{\text {th }}-15^{\text {th }}\right.$ century), who has been assumed by several historiographies: Bulgarian, Romanian, Serbian, Russian, and Ukrainian. The final essay is entitled «Folklore as historical source», inviting students to discuss the Romanian - South Slavic cultural connections on the level of folklore.

Topic XI is dedicated to the historical connections to Poland, extremely close and tight throughout the Middle Ages and the Early Modern Period especially with Moldavia (including the issue of how Moldavia was founded, its vassality to Poland, the issue of Pokuttya / Pokutsia, the Moldavian-Polish relations regarding the Ottoman issue, political, cultural, social, institutional tis etc.). One of the essays discusses «Who was "Ia $\square$ co the beekeeper"»? The question arises from reading an episode in Grigore Ureche's Letopise $\square$, interpolated by Simion Dascălul (1 $7^{\text {th }}$ century). The episode mentions how the legendary Drago $\square$, native of Maramureş, reached Moldavia while hunting and met Ia $\square$ co, «a Rus' from the Polish country» ${ }^{41}$. This legend probably started from the cultural and political choices of some groups of Moldavian boyars from the $14^{\text {th }}$ century, as historian Ovidiu Pecican attempted to interpret them ${ }^{42}$. The other essay presents «Poland in the writings of Grigore Ureche and Miron Costin», namely the biographical, political, and cultural connections of the two chronicler boyars with Poland during the $17^{\text {th }}$ century and the way in which Poland was regarded.

The final topic of «The Slavs and Slavonism in the Medieval and Early Modern History of the Romanians» course and seminar is dedicated to the historical connections to the North and East Slavic areas (Russia, Ukraine, the Kazakhs) (topic XII), through a general presentation of the subject and through essays. The first part discusses the early period of Moldavia, the first connections to Kievan Rus', the time of Stephen the Great, the connections during the $16^{\text {th }}-17^{\text {th }}$ centuries, the role that Kazakhs played in the history of Moldavia, and the time of Peter the Great $^{43}$. The topics of the essays suggested to the students are related to subjects of interest: «The image of the Kazakhs in the writings of Miron Costin» ${ }^{44}$, «Nicolae Milescu Spătarul in Russia», and «Dimitrie Cantemir in Russia». The essay focusing on Nicolae Milescu follows

41 Ciobanu V. Ţările Române şi Polonia, sec. XIV-XVI. Bucureşti, 1985. P. 15-111; Rezachevici $C$. Istoria popoarelor vecine şi neamul românesc în evul mediu. P. 37-241.

42 Ureche G. Letopisețul Țării Moldovei. Bucureşti, 1958. P. 68-70; Costin M. Opere. Bucureşti, 1958. P. 230-235.

43 Pecican O. Troia, Veneția, Roma. P. 282-290. Also see: Spinei V. Moldova în secolele XIXIV. Chişinău, 1994. P. 233-243.

44 Dvornik F. Slavii în istoria şi civilizația europeană. P. 189-205, 320-343, 384-481; Rezachevici $C$. Istoria popoarelor vecine şi neamul românesc în evul mediu. P. 381-477; Solomon F. Politică şi confesiune la început de ev mediu moldovenesc. Iaşi, 2004. P. 67-81, 127-153; Relaţii romîno-ruse în trecut. Studii şi conferințe. Bucureşti, 1957. P. 3-95; Relații româno-ucrainene. Istorie şi contemporaneitate / Ed by V. Ciobotă, V. Marina. Satu Mare, 1999. P. 169-290. 
his diplomatic career, especially in the service of Russia, and his diplomatic mission to China, described in a spectacular travelling account ${ }^{45}$. As for Dimitrie Cantemir, the focus is placed on the period he had spent in Russia, around Tsar Peter the Great. We are interested not in Cantemir's political, but in his scientific activity, in his interest for the Ottoman Empire and the Orient, his capacity of Orientalist and the books he wrote in Russian context ${ }^{46}$.

I would now like to make several bibliographic observations. The course has a general bibliography and an additional bibliography and there are specific bibliographies for each course / seminar topic, just as there is one for essays and presentations. A rich bibliography on the topic is available in the Romanian context. Naturally, it will never be sufficient, but it does cover the requirements of the course on the history of the Slavs. One can turn to studies, articles, and books by Romanian authors or to Romanian translations of foreign authors (such as Dimitri Obolensky, Francis Dvornik, and Florin Curta), but I did not avoid suggesting titles of works in international languages (English, French, and German). As a general principle, I tried to offer to the students a balanced bibliography, as much as possible (Romanian vs. foreign authors), and as easily accessible as possible (books available in public libraries or online publications). I sometimes privileged older works (published during the 1950s and the 1960s), since I try to convince my students to read older texts as well, not only the literature of the last $15-20$ years.

There is no general work on the history of the Slavs written by a Romanian author, just the translations of the known synthesis by Francis Dvornik or of Florin Curta's work, besides Dimitri Obolensky's excellent work on the Byzantine Commonwealth. In Romanian language general literature on the history of the Slavs is lean, but I compensated with the great synthesis works published by F. Dvornik, F. Comte, and A. V. Vlasto and with studies and articles dedicated to certain topics or aspects from the history of the Slavs. Romanian historiography is richer on topics regarding the connections between the Romanians and the Slavs, such as Constantin Rezachevici's synthesis on the subject. In order to encourage students to read, I did not stress the large syntheses that would have easily provided them with the necessary information, but I encouraged them to use a lot of secondary literature instead. This is visible in the extremely varied bibliography suggested for each course or seminar topic.

For some of the topics the bibliography includes medieval sources, some of which are anyway part of the material discussed during class or of the seminar activities. As the course is general in scope and in order to ease the students' access to information, I have provided sources in Romanian and international languages, not in their original languages.

The lectures are delivered with the aid of projected PowerPoint presentations in order to aid the students remember ideas, names, and images. Excerpts from the written sources are similarly presented, so that the texts are read and commented upon together. I must also note the large number of maps employed for a better understanding of the historical processes in their geographic contexts (the migration of the Slavs, maps of Central and Eastern Europe during the Middle Ages, the Byzantine Empire, Kievan Rus', the First Bulgarian Tsardom,

45 Costin M. Opere. P. 123-125, 134-135, 148-149; Mazilu D. Noi despre ceilalţi. Fals tratat de imagologie. Iaşi, 1999. P. 160-165.

46 Milescu N. Jurnal de călătorie în China. Bucureşti, 1987 or Milescu N. 1) Călătorie în China, 1675-1677. Bucureşti, 1941; 2) Descrierea Chinei. Bucureşti, 1958. 
medieval Serbia, Croatia, Bosnia, Great Moravia, Poland-Lituania). I also discuss with my students the ideological charge of historical maps.

In the end of my presentation I shall draw several conclusions. As one can note, the university course dedicated to «The Slavs and Slavonism in the Medieval and Early Modern History of the Romanians» is based on an analytical and not on a chronological approach, with topics of general history (the general history of the Slavs) backed by subjects regarding the history of the Romanians (in direct connection to the history of the Slavs). For didactical reasons I preferred to stress the great historical processes, mainly those that are connected to the history of the Romanians. The topics are thus structured with a mind towards the beneficiaries of this course - the students and their needs - providing an introduction into the history of the Slavs and their historical connections to the Romanians, through modern concepts and issues and with the aid of equally modern working tools.

Данные о статье

Автор: Мырза, Раду — доктор истории, профессор, Университет Бабеш-Бойяи, Клуж-Напока, Румыния, rmarza@yahoo.com

Заголовок: Teaching Slavic History in Romania in 2017 (Преподавание истории славян в Румынии в 2017 г.)

Резюме: Изучение истории славян в Румынии имеет вековую традицию. Оно берет начало с открытия первых курсов «Славянской филологии» в университетах Бухареста и Ясс профессоров Иоана Богдана (1891) и Или Бэрбулеску (1905). С тех пор в румынских университетах всегда были кафедры славяноведения и славянской истории. В Университете Клуж-Напока в 1919 г. была основана кафедра славянской и юго-восточно-европейской истории. В настоящее время славянские языки, культуры и литература преподаются в Университете Бабеш-Боляй в Клуж-Напоке, на филологическом факультете. На факультете истории и философии того же университета с 2005 г. я преподаю курс «Славяне и славянизм в румынской истории». В статье обсуждается культурный контекст преподавания славянской истории, языка и культуры в современной Румынии. Преподаватель должен адаптировать свой дискурс к культурному и образовательному опыту студентов.

Ключевые слова: славянские исследования, Румыния, история славян, славяно-румынские отношения, историография, Университеты в Румынии, Университет Бабеш-Боляй в Клуже

Литература, использованная в статье

Alzati, Cesare. În inima Europei. Studii de istorie religioasă a spaţiului românesc / Ed. de Şerban Turcuş. Cluj-Napoca: Centrul de Studii Transilvane, Fundația Culturală Română, 1998. 237 p.

Bărbulescu, Ilie. Problemele capitale ale Slavisticei la Români. Iaşi: [s. n.], 1906. 51 p.

Bogdan, Ioan. Însemnătatea studiilor slave pentru Români. Bucureşti: Ed. Socecu, 1894. 41 p.

Ciobanu, Veniamin. Țările Române şi Polonia, sec. XIV-XVI. București: Ed. Academiei Republicii Socialiste România, 1985. 112 p.

Costin, Miron. Opere. Ediție critică de Petre P. Panaitescu. Bucureşti: Ed. de Stat pentru Literatură şi Artă, 1958. $533 \mathrm{p}$.

Curta, Florin. The changing image of the Early Slavs in the Rumanian historiography and archeological literature // Südost-Forschungen. 1994. T. 53. P. 225-310.

Curta, Florin. The Making of the Slavs: History and Archaeology of the Lower Danube Region, c. 500-700. Cambridge: Cambridge University Press, 2001. 463 p. (Romanian edition: Curta, Florin. Apariția slavilor. Istorie şi arheologie la Dunărea de Jos în veacurile VI-VII. Târgovişte: Ed. Cetatea de Scaun, 2006. 414 p.). Dvornik, Francis. Slavii în istoria şi civilizaţia europeană. Bucureşti: Ed. ALL, 2001. 636 p.

Geambaşu, Constantin (ed.). Catedra de limbi şi literaturi slave. Scurt istoric. Bucureşti: Ed. Universităţii din Bucureşti, 2008. 176 p.

Ghitta, Ovidiu. Silviu Dragomir, historien des relations ecclesiastiques roumano-russes // Transylvanian Review. 1993. T. II. No. 2. P. 53-59.

Grecu, Al. [Panaitescu, Petre P.]. Bulgaria în nordul Dunării în veacurile al IX-X-lea // Studii şi Cercetări de Istorie Medie. 1950. T. I. No. 1. P. 223-236. 
Harea, Vasile. Dimitrie Cantemir şi fiul său Antioh. Studii / Ed. by Sorina Bălănescu. Iaşi: Ed. Universității din Iaşi, 1999. 240 p.

Istoria minorităților naționale din România. Material auxiliar pentru profesorii de istorie / Ed. by Doru Dumitrescu, Carol Căpi $\square$ ă, Mihai Manea. Bucureşti: Ed. Didactică şi Pedagogică, 2008. 279 p.

Lemerle, Paul. Les plus anciens recueils des miracles de Saint Démétrius et la pénétration des Slaves dans les Balkans. Vol. I. Paris: Éditions du CNRS, 1979. 268 p.

Lința, Elena (ed.). Din istoricul slavisticii româneşti. Bucure $\square$ ti: Universitatea din Bucureşti, 1982. 404 p. Macuirek, Josef. Valaši v západních Karpatech v 15.-18. století. K dějinám osídlení hospodářskospolečenského vývoje jižního Těšínska, jihozápadního Polska, severozápadního Slovenska a východní Moravy. Ostrava: Krajské nakladatelství, 1959. 528 p.

Mazilu, Dan Horia. Noi despre ceilalţi. Fals tratat de imagologie. Iaşi: Ed. Polirom, 1999. 264 p.

Mârza, Radu. A Bibliography of Bogdan Petriceicu Hasdeu's Concerns in the Field of Slavonic Studies // Transylvanian Review. 2003. Vol. XII. No. 2. P. 118-130.

Mârza, Radu. Identitățile slave ale lui Bogdan Petriceicu Hasdeu, in Identitate şi alteritate. 4. Studii de istorie politică şi culturală / Ed. by Constantin Bărbulescu, Luminița Dumănescu, Sorin Mitu, Vlad Popovici. ClujNapoca: Ed. Argonaut, 2007. P. 259-273.

Mârza, Radu. Ilie Bărbulescu $\square$ i înfiin $\square$ area catedrei de limbi slavice la Universitatea din Ia $\square$ i. Contribu $\square$ ii documentare // Clio în oglindiri de sine. Academicianului Alexandru Zub. Omagiu / Ed. by Gheorghe Cliveti. Iaşi: Ed. Universită $\square$ ii Al. I. Cuza, 2014. P. 631-660.

Mârza, Radu. Ioan Bogdan: His Education and Career in the Field of Slavonic Studies // Transylvanian Review. Spring, 2006. T. XV. No. 1. P. 3-26.

Mârza, Radu. Istoricul Mihail P. Dan (1911-1976) // Caietele «David Prodan». Ianuarie-iunie, 1994. T. I. No. 1. P. 50-57.

Mârza, Radu. Recitindu-i pe clasici. Lecțiile inaugurale ale lui Ioan Bogdan (1891) şi Ilie Bărbulescu (1905) // Romanoslavica. 2009. T. XLV. P. 153-166 (URL : http://www.romanoslavica.ro).

Mârza, Radu. Recitindu-l pe Panaitescu: Bulgaria în nordul Dunării // Studii de istoriografie românească / Ed. by Gabriel Moisa. Cluj: Ed. Dacia, 2008. P. 159-178.

Mârza, Radu. Slavistica şi formaţia istorică a lui Silviu Dragomir // Silviu Dragomir. 120 de ani de la naştere / Ed. by Ioan-Aurel Pop, Sorin Şipoş. Oradea: Ed. Universității din Oradea, 2011. P. 197-208.

Mârza, Radu. The History of Romanian Slavic Studies. From the Beginnings until the First World War. ClujNapoca: Ed. Academiei Române, Centrul de Studii Transilvane, 2008. 624 p.

Mihăilă, Gheorghe (ed.). Bogdan, Ioan. Scrieri alese. Bucureşti: Ed. Academiei Republicii Socialiste România, 1968. 709 p.

Mihăilă, Gheorghe. Cultură şi literatură română veche în context european. Studii şi texte. Bucureşti: Ed. Ştiințifică şi Enciclopedică, 1979. 430 p.

Mihăilăa, Gheorghe. Între Orient şi Occident. Studii de cultură şi literatură română în secolele al XV-lea - al XVIII-lea. Bucureşti: Ed. Roza Vânturilor, 1999. 399 p.

Mihăilă, Gheorghe. Langue et culture roumaine dans l'éspace sud-est-européen. Bucureşti: Ed. Academiei Române, 2001.713 p.

Mihăilă, Gheorghe. O sută de ani de studii slavo-române la Universitatea din Bucureşti // Romanoslavica. 1992. T. XXIX. P. 15-56.

Mihăilă, Gheorghe. Slavistica românească după 1944 şi sarcinile ei actuale (Lucrările de lingvistică) // Romanoslavica. 1960. T. IV. P. 5-34.

Mihăilă, Gheorghe. Studii de lexicologie şi istorie a lingvisticii româneşti. Bucureşti: Ed. Didactică şi Pedagogică, 1973. 228 p.

Mihăilă, Gheorghe. Studii de lingvistică şi filologie. Timişoara: Ed. Facla, 1981. 292 p.

Milescu, Nicolae. Călătorie în China, 1675-1677. Bucureşti: Monitorul Oficial, 1941. 224 p.

Milescu, Nicolae. Descrierea Chinei. București: ESPLA, 1958. 287 p.

Milescu, Nicolae. Jurnal de călătorie în China. Bucureşti: Ed. Minerva, 1987. 399 p.

Mitu, Mihai. Slavona românească. Bucureşti: Ed. Universității din Bucureşti, 2002. 84 p.

Morfill, William Richard. An Essay on the Importance of the Study of the Slavonic Languages. Inaugural Lecture. Oxford, 1890. 33 p.

Niță-Armaş, Silvia. În jurul problemei cuvintelor de origine românească în limba slovacă // Studii şi cercetări lingvistice. 1966. T. XVII. No. 5. P. 579-591. 
Niță-Armaş, Silvia; Pavliuc, Nicolae; Gămulescu, Dorin. L'influence roumaine sur de lexique des langues slaves // Romanoslavica. 1968. T. XVI. P. 69-101.

Obolensky, Dimitri. The Byzantine Commonwealth. New York: Praeger Publishers, 1971. 445 p. (Romanian edition: Obolensky, Dimitri. Un commonwealth medieval: Bizanțul. Europa de răsărit 500-1453. Bucureşti: Ed. Corint, 2002. 526 p.).

Obolensky, Dimitri. The Cult of St. Demetrius of Thessaloniki in the History of Byzantine-Slav Relations // Balkan Studies. 1974. T. 15. P. 3-22.

Olteanu, Pandele. Aux origines de la culture slave dans la Transylvanie de Nord et le Maramureş // Romanoslavica. 1958. T. I. P. 169-197.

Olteanu, Pandele (ed.). Slava veche şi slavona românească. Bucureşti: Ed. Didactică şi Pedagogică, 1975. $464 \mathrm{p}$.

Ornea, Zigu. Junimea şi junimismul. Bucureşti: Ed. Eminescu, 1975. 670 p. (new editions - 1978, 1998).

Panaitescu, Petre P. Contribuții la istoria culturii româneşti. Bucureşti: Ed. Minerva, 1971. 639 p.

Panaitescu, Petre P. Dimitrie Cantemir. Viața şi opera. Bucureşti: Ed. Academiei Republicii Populare Române, 1958. 268 p.

Panaitescu, Petre P. Interpretări româneşti. Studii de istorie economică şi socială. Bucureşti: Ed. Enciclopedică, 1994. 264 p. $\left(1^{\text {st }}\right.$ ed. - 1947).

Pecican, Ovidiu. B. P. Hasdeu istoric. Cluj-Napoca: Casa Cărții de Ştiință, 2004. 320 p.

Pecican, Ovidiu. Troia, Veneția, Roma. Studii de istoria civilizației europene. Cluj-Napoca: Ed. Fundației pentru Studii Europene, 1998. 448 p.

Petrovici, Emil. Studii de dialectologie şi toponimie. Bucureşti: Ed. Academiei Republicii Socialiste România, $1970.339 \mathrm{p}$.

Relații româno-bulgare de-a lungul veacurilor (sec. XII-XIX). Vol. I. Bucureşti: Ed. Academiei Republicii Socialiste România, 1971. 435 p.

Relații romîno-ruse în trecut. Studii şi conferințe. București: Academia Republicii Populare Române. Institutul de Studii Romîno-Sovietic, 1957. 324 p.

Relații româno-ucrainene. Istorie şi contemporaneitate / Ed. by Viorel Ciobotă, Vasile Marina. Satu Mare: Ed. Muzeului Sătmărean, 1999. 578 p.

Rezachevici, Constantin. Istoria popoarelor vecine şi neamul românesc în evul mediu. Bucureşti: Ed. Albatros, $1998.596 \mathrm{p}$.

Sala, Marius. Introducere în etimologia limbii române. Bucureşti: Ed. Academiei Române, 2005. 254 p.

Solomon, Flavius. Politică şi confesiune la început de ev mediu moldovenesc. Iaşi: Ed. Universității Al. I. Cuza, 2004. 272 p.

Spinei, Victor. Moldova în secolele XI-XIV. Chişinău: Ed. Universitas, 1994. 496 p.

Stanciu, Ion. Slavii timpurii în cercetarea arheologică românească // Ephemeris Napocensis. 2001. T. XI. P. 105-132.

Ureche, Grigore. Letopisețul Țării Moldovei / Ed. de Petre P. Panaitescu. Ediția a II-a. Bucureşti: Ed. de Stat pentru Literatură şi Artă, 1958. 262 p.

Vlasto, Alexis Peter. The Entry of the Slavs into Christendom. Cambridge: Cambridge University Press, 1970. $435 \mathrm{p}$.

\section{Information about the article}

Author: Mârza, Radu — Doctor in History, Professor, Babe $\square$-Bolyai University, Cluj-Napoca, Romania, rmarza@yahoo.com

Title: Teaching Slavic History in Romania in 2017

Summary: The teaching of Slavic History in Romania has a tradition of over one century. It started systematically with the opening of the first chairs of «Slavic Philology» at the Bucharest and Iaşi Universities (Professors Ioan Bogdan, Ilie Bărbulescu) in 1891, respectively in 1905. Since then, Romanian universities have always had chairs and departments of Slavic Studies and Slavic History. At the University of Cluj, a Chair of Slavic and South-East-European History was founded in 1919. Today, Slavic languages, cultures and literatures are taught at Babeş-Bolyai University in Cluj, at the Faculty of Letters. At the Faculty of History and Philosophy of the same university I have been teaching a course entitled «Slavs and Slavonism in Romanian History» since 2005. My paper will discuss the cultural context for teaching Slavic history, language and cultures in today's Romania, as well as several concrete teaching approaches I have adopted in this area. The students' cultural and educational background is important: it is an interesting consequence 
of a larger cultural context and the teacher must adapt his discourse to it. I will also discuss the topics of the lectures, their structure, the sources we discuss in the seminars, and the literature offered to the students for reading.

Keywords: Slavic studies, Romania, history of the Slavs, Slavic-Romanian relations, historiography, universities in Romania, Babe $\square$-Bolyai University in Cluj

\section{References}

Alzati, Cesare. În inima Europei. Studii de istorie religioasă a spațiului românesc [In the hearth of Europe. Studies of religious history of the Romanian territory]. Ed. de Şerban Turcuş. Cluj-Napoca: Centrul de Studii Transilvane, Fundația Culturală Română Publ., 1998. 237 p. (in Romanian).

Bărbulescu, Ilie. Problemele capitale ale Slavisticei la Români [Capital issues of the Slavic studies in Romania]. Iaşi: [s. n.], 1906. 51 p. (in Romanian).

Bogdan, Ioan. Insemnătatea studiilor slave pentru Români [Importance of Slavic studies in Romania]. Bucureşti: Socecu Publ., 1894. 41 p. (in Romanian).

Ciobanu, Veniamin. Țările Române şi Polonia, sec. XIV-XVI [Romanian countries and Poland, $14^{\text {th }}-16^{\text {th }}$ centuries]. Bucureşti: Ed. Academiei Republicii Socialiste România, 1985. 112 p. (in Romanian).

Costin, Miron. Opere [Works]. Ediție critică de Petre P. Panaitescu. Bucureşti: Ed. de Stat pentru Literatură şi Artă, 1958. 533 p. (in Romanian).

Curta, Florin. The changing image of the Early Slavs in the Rumanian historiography and archeological literature, in Südost-Forschungen. 1994. Vol. 53. P. 225-310.

Curta, Florin. The Making of the Slavs: History and Archaeology of the Lower Danube Region, c. 500-700. Cambridge: Cambridge University Press, 2001. 463 p.

Curta, Florin. Apariția slavilor. Istorie şi arheologie la Dunărea de Jos în veacurile VI-VII [The Making of the Slavs: History and Archaeology of the Lower Danube Region, c. 500-700]. Târgovişte: Cetatea de Scaun Publ., 2006. 414 p. (in Romanian).

Dvornik, Francis. Slavii în istoria şi civilizația europeană [The Slavs in European history and civilization]. Bucureşti: ALL Publ., 2001. 636 p. (in Romanian).

Geambaşu, Constantin (ed.). Catedra de limbi şi literaturi slave. Scurt istoric [The department of Slavic languages and literatures]. Bucureşti: Ed. Universităţii din București, 2008. 176 p. (in Romanian).

Ghitta, Ovidiu. Silviu Dragomir, historien des relations ecclesiastiques roumano-russes [Silviu Dragomir, historian of the Romanian-Russian religious relations], in Transylvanian Review. 1993. Vol. II. No. 2. P. 53-59 (in Romanian).

Grecu, Al. [Panaitescu, Petre P.]. Bulgaria în nordul Dunării în veacurile al IX-X-lea [Bulgaria at the north of Danube during the $9^{\text {th }}-10^{\text {th }}$ centuries], in Studii şi Cercetări de Istorie Medie. 1950. Vol. I. No. 1. P. 223-236 (in Romanian).

Harea, Vasile. Dimitrie Cantemir şi fiul său Antioh. Studii [Dimitrie Cantemir and his son Antioh. Papers]. Ed. by Sorina Bălănescu. Iaşi: Ed. Universităţii din Iaşi, 1999. 240 p. (in Romanian).

Istoria minorităților naționale din România [History of the national minorities in Romania]. Material auxiliar pentru profesorii de istorie. Ed. by Doru Dumitrescu, Carol Căpi $\square$ ă, Mihai Manea. Bucureşti: Didactică şi Pedagogică Publ., 2008. 279 p. (in Romanian).

Lemerle, Paul. Les plus anciens recueils des miracles de Saint Démétrius et la pénétration des Slaves dans les Balkans [The earliest information on the miracles of St. Demetrius and the penetration of the Slavs into the Balkans]. Vol. I. Paris: CNRS Publ., 1979. 268 p. (in French).

Lința, Elena (ed.). Din istoricul slavisticii româneşti [From the history of the Romanian Slavic studies]. Bucure $\square$ ti: Universitatea din Bucureşti Press, 1982. 404 p. (in Romanian).

Macůrek, Josef. Valaši v západních Karpatech v 15.-18. století. K dějinám osídlení a hospodářrskospolečenského vývoje jižního Těšinska, jihozápadního Polska, severozápadniho Slovenska a východni Moravy [Valachians in the western Carpathians in the $15^{\text {th }}-18^{\text {th }}$ centuries. Contributions to the history of the colonisation and social-economic evolution of the southern Těšin, south-western Poland, north-western Slovakia and eastern Moravia]. Ostrava: Krajské nakladatelství Publ., 1959. 528 p. (in Romanian).

Mazilu, Dan Horia. Noi despre ceilalți. Fals tratat de imagologie [We about the others. Fake dissertation of imagology]. Iaşi: Polirom Publ., 1999. 264 p. (in Romanian).

Mârza, Radu. A Bibliography of Bogdan Petriceicu Hasdeu's Concerns in the Field of Slavonic Studies, in Transylvanian Review. 2003. Vol. XII. No. 2. P. 118-130.

Mârza, Radu. Identitățile slave ale lui Bogdan Petriceicu Hasdeu [Slavic identities of Bogdan Petriceicu Hasdeu], in Identitate şi alteritate. 4. Studii de istorie politică şi culturală. Ed. by Constantin Bărbulescu, 
Luminița Dumănescu, Sorin Mitu, Vlad Popovici. Cluj-Napoca: Argonaut Publ., 2007. P. 259-273 (in Romanian).

Mârza, Radu. Ilie Bărbulescu $\square$ i înfiin $\square$ area catedrei de limbi slavice la Universitatea din Ia $\square$ i. Contribu $\square$ ii documentare [Ilie Bărbulescu and the foundation of the chair of Slavic languages at the University in Ia $\square$ i. Documentary contributions], in Cliveti, Gheorghe (ed.). Clio in oglindiri de sine. Academicianului Alexandru Zub. Omagiu. Iaşi: Ed. Universită $\square$ ii Al. I. Cuza, 2014. P. 631-660 (in Romanian).

Mârza, Radu. Ioan Bogdan: His Education and Career in the Field of Slavonic Studies, in Transylvanian Review. Spring, 2006. Vol. XV. No. 1. P. 3-26.

Mârza, Radu. Istoricul Mihail P. Dan (1911-1976) [The historian Mihail P. Dan (1911-1976)], in Caietele «David Prodan». Ianuarie-iunie, 1994. Vol. I. No. 1. P. 50-57 (in Romanian).

Mârza, Radu. Recitindu-i pe clasici. Lecțiile inaugurale ale lui Ioan Bogdan (1891) şi Ilie Bărbulescu (1905) [Rereading the classics. The inaugural lectures of Ioan Bogdan (1891) and Ilie Bărbulescu (1905)], in Romanoslavica. 2009. Vol. XLV. P. 153-166 (URL: http://www.romanoslavica.ro) (in Romanian).

Mârza, Radu. Recitindu-l pe Panaitescu: Bulgaria în nordul Dunării [Rereading Panaitescu: Bulgaria at the north of Danube], in Moisa, Gabriel (ed.). Studii de istoriografie românească. Cluj: Dacia Publ., 2008. P. 159-178 (in Romanian).

Mârza, Radu. Slavistica şi formaţia istorică a lui Silviu Dragomir [Slavic studies and the formation of the historian Silviu Dragomir], in Pop, Ioan-Aurel Pop; Şipoş, Sorin (eds). Silviu Dragomir. 120 de ani de la naştere. Oradea: Ed. Universității din Oradea, 2011. P. 197-208 (in Romanian).

Mârza, Radu. The History of Romanian Slavic Studies. From the Beginnings until the First World War. ClujNapoca: Ed. Academiei Române, Centrul de Studii Transilvane, 2008. 624 p.

Mihăilă, Gheorghe. Cultură şi literatură română veche în context european. Studii şi texte [Old Romanian culture and literature in European context. Papers and texts]. Bucureşti: Ştiințifică şi Enciclopedică Publ., 1979. 430 p. (in Romanian).

Mihăilă, Gheorghe (ed.). Bogdan, Ioan. Scrieri alese [Bogdan, Ioan. Selected works]. Bucureşti: Ed. Academiei Republicii Socialiste România, 1968. 709 p. (in Romanian).

Mihăilă, Gheorghe. Intre Orient şi Occident. Studii de cultură şi literatură română în secolele al XV-leaal XVIII-lea [Between East and West. Studies on the Romanian culture and literature during the $15^{\text {th }}-18^{\text {th }}$ centuries]. Bucureşti: Roza Vânturilor Publ., 1999. 399 p. (in Romanian).

Mihăilă, Gheorghe. Langue et culture roumaine dans l'éspace sud-est-européen [Romanian language and culture in the south-east-european area]. București: Ed. Academiei Române, 2001.713 p. (in Romanian).

Mihăilă, Gheorghe. O sută de ani de studii slavo-române la Universitatea din Bucureşti [Hundred years of Slavic-Romanian studies at the University in Bucharest], in Romanoslavica. 1992. Vol. XXIX. P. 15-56 (in Romanian).

Mihăilă, Gheorghe. Slavistica românească după 1944 şi sarcinile ei actuale (Lucrările de lingvistică) [The Romanian Slavic studies after 1944 and its current tasks. The works on linguistics], in Romanoslavica. 1960. Vol. IV. P. 5-34 (in Romanian).

Mihăilă, Gheorghe. Studii de lexicologie şi istorie a lingvisticii româneşti [Studies of lexicology and history of the Romanian linguistics]. Bucureşti: Didactică şi Pedagogică Publ., 1973. 228 p. (in Romanian).

Mihăilă, Gheorghe. Studii de lingvistică şi filologie [Studies of linguistics and philology]. Timişoara: Facla Publ., 1981. 292 p. (in Romanian).

Milescu, Nicolae. Călătorie în China, 1675-1677 [Travel to China, 1675-1677]. București: Monitorul Oficial Publ., 1941. 224 p. (in Romanian).

Milescu, Nicolae. Descrierea Chinei [Description of China]. Bucureşti: ESPLA Publ., 1958. 287 p. (in Romanian).

Milescu, Nicolae. Jurnal de călătorie în China [Diary of the travel to China]. Bucureşti: Minerva Publ., 1987. 399 p. (in Romanian).

Mitu, Mihai. Slavona românească [The Romanian Slavonic language]. Bucureşti: Ed. Universității din Bucureşti, 2002. 84 p. (in Romanian).

Morfill, William Richard. An Essay on the Importance of the Study of the Slavonic Languages. Inaugural Lecture. Oxford, 1890. 33 p.

Niță-Armaş, Silvia. În jurul problemei cuvintelor de origine românească în limba slovacă [On the question of the words of Romanian origin in the Slovak language], in Studii şi cercetări lingvistice. 1966. Vol. XVII. No. 5. P. 579-591 (in Romanian). 
Niță-Armaş, Silvia; Pavliuc, Nicolae; Gămulescu, Dorin. L'influence roumaine sur de lexique des langues slaves [The Romanian influence on the lexic of the Slavic languages], in Romanoslavica. 1968. Vol. XVI. P. 69-101 (in French).

Obolensky, Dimitri. The Byzantine Commonwealth. New York: Praeger Publ., 1971. 445 p.

Obolensky, Dimitri. Un commonwealth medieval: Bizanțul. Europa de răsărit 500-1453 [A medieval Commonwealth: Byzantium. Eastern Europe 500-1453]. Bucureşti: Corint Publ., 2002. 526 p. (in Romanian). Obolensky, Dimitri. The Cult of St. Demetrius of Thessaloniki in the History of Byzantine-Slav Relations, in Balkan Studies. 1974. Vol. 15. P. 3-22.

Olteanu, Pandele. Aux origines de la culture slave dans la Transylvanie de Nord et le Maramureş [On the origins of the Slavic culture in the northern Transylvania and Maramure $\square$ ], in Romanoslavica. 1958. Vol. I. 1958. P. 169-197 (in French).

Olteanu, Pandele (ed.). Slava veche şi slavona românească [The old Slavic and the Romanian Slavonic language]. Bucureşti: Didactică şi Pedagogică Publ., 1975. 464 p. (in Romanian).

Ornea, Zigu. Junimea şi junimismul [Junimea and its spirit]. Bucureşti: Eminescu Publ., 1975. 670 p. (new editions - 1978, 1998) (in Romanian).

Panaitescu, Petre P. Contribuții la istoria culturii româneşti [Contributions to the history of the Romanian culture]. Bucureşti: Minerva Publ., 1971. 639 p. (in Romanian).

Panaitescu, Petre P. Dimitrie Cantemir. Viața şi opera [Dimitrie Cantemir. Life and oeuvre]. Bucureşti: Ed. Academiei Republicii Populare Române, 1958. 268 p. (in Romanian).

Panaitescu, Petre P. Interpretări româneşti. Studii de istorie economică şi socială [Romanian interpretations. Strudies of economical and social history]. Bucureşti: Enciclopedică Publ., 1994. 264 p. (1 $1^{\text {st }}$ ed. - 1947) (in Romanian).

Pecican, Ovidiu. B. P. Hasdeu istoric [B. P. Hasdeu as a historian]. Cluj-Napoca: Casa Cărții de Ştiință Publ., 2004. 320 p. (in Romanian).

Pecican, Ovidiu. Troia, Veneția, Roma. Studii de istoria civilizației europene [Troy, Venice, Rome. Studies of history of the European civilisation]. Cluj-Napoca: Ed. Fundației pentru Studii Europene, 1998. 448 p. (in Romanian).

Petrovici, Emil. Studii de dialectologie şi toponimie [Studies of dialectology and toponymy]. Bucureşti: Ed. Academiei Republicii Socialiste România, 1970. 339 p. (in Romanian).

Relații româno-bulgare de-a lungul veacurilor (sec. XII-XIX) [Romanian-Bulgarian relations during the centuries (12 $2^{\text {th }}-19^{\text {th }}$ centuries)]. Vol. I. Bucureşti: Ed. Academiei Republicii Socialiste România, 1971. 435 p. (in Romanian).

Relații romîno-ruse în trecut [Romanian-Russian relation in the past]. Studii şi conferințe. Bucureşti: Academia Republicii Populare Române, Institutul de Studii Romîno-Sovietic Press, 1957. 324 p. (in Romanian).

Relații româno-ucrainene. Istorie şi contemporaneitate [Romanian-Ucrainian relations. History and contemporaneity]. Ed. by Viorel Ciobotă, Vasile Marina. Satu Mare: Ed. Muzeului Sătmărean, 1999. 578 p. (in Romanian).

Rezachevici, Constantin. Istoria popoarelor vecine şi neamul românesc în evul mediu [History of the neighboring nations and the Romanians during the middle ages]. Bucureşti: Albatros Publ., 1998. 596 p. (in Romanian).

Sala, Marius. Introducere în etimologia limbii române [Introduction to the etymology of the Romanian language]. Bucureşti: Ed. Academiei Române, 2005. 254 p. (in Romanian).

Solomon, Flavius. Politică şi confesiune la început de ev mediu moldovenesc [Politics and confession at the beginning of the Moldavian middle ages]. Iaşi: Ed. Universităţii Al. I. Cuza, 2004. 272 p. (in Romanian).

Spinei, Victor. Moldova in secolele XI-XIV [Moldavia during the $11^{\text {th }}-14^{\text {th }}$ centuries]. Chişinău: Universitas Publ., 1994. 496 p. (in Romanian).

Stanciu, Ion. Slavii timpurii în cercetarea arheologică românească [Early Slavs into the Romanian archaeological research], in Ephemeris Napocensis. 2001. Vol. XI. P. 105-132 (in Romanian).

Ureche, Grigore. Letopisețul Țării Moldovei [The chronicle of Moldavia]. Ed. by Petre P. Panaitescu. Ediția a II-a. Bucureşti: Ed. de Stat pentru Literatură şi Artă, 1958. 262 p. (in Romanian).

Vlasto, Alexis Peter. The Entry of the Slavs into Christendom. Cambridge: Cambridge University Press, 1970. $435 \mathrm{p}$. 